challenge in an era of uncertainty for healthcare systems worldwide.

The influence of genetic and molecular medicine on the health of patients is already sufficiently ubiquitous that it will have an impact on most common diseases. Its influence will grow over the next few decades (Table 1). It will not, however, answer all of the questions about human health, nor will it provide all the answers for optimizing clinical practice. The reductionism that accompanies molecular genetics will identify the pieces in the jigsaw, but assembling these to understand how complex systems malfunction will require a substantially more integrated approach than is available at present.

The crucial role played by environmental determinants of disease will perhaps become more tractable when combined with an understanding of genetic susceptibility. Sceptics, rightly, will wish to see more data before they acknowledge that molecular medicine will be truly transformed over the next 50 years, despite the fact that its influence on diagnostics and new therapeutics is already clearly apparent. A transition is underway, the direction of travel is clear, but managing the change in clinical practice may prove at least as challenging as resolving the original structure of the helix.

doi:10.1038/nature01402

1. Watson, J. D. \& Crick, F. C. H. A structure for deoxyribose nucleic acid. Nature 171, 737-738 (1953).

2. Abraham, E. P. et al. Further observations on penicillin. Lancet ii, 177-188 (1941)

3. Doll, R. \& Hill, A. B. Smoking and carcinoma of the lung. Br. Med. J. 2, 739-748 (1950).

4. Fisher, R. A. Cancer and smoking. Nature 182, 596 (1958).

5. Holtzman, N. A. \& Marteau, T. M. Will genetics revolutionise medicine? N. Engl. J. Med. 343, 141-144 (2000).

6. Bell, J. I. The new genetics in clinical practice. Br. Med. J. $\mathbf{3 1 6}$ 618-620 (1998).

. Osler, W. The Principles and Practice of Medicine (Appleton, $\mathrm{New}$ York, 1892).

8. Lewis, T. Reflections upon medical education. Lancet i, 619-621 (1944).

9. Cardon, L. R. \& Bell, J. I. Association study designs for complex diseases. Nature Rev. Genet. 2, 91-99 (2001).

10. Van Eerdewegh, P. et al. Association of the ADAM33 gene with asthma and bronchial hyperresponsiveness. Nature 418, 426-430 (2002).

11. Cookson, W. O. C. M., Sharp, P. A., Faux, J. A. \& Hopkin, J. M. Linkage between immunoglobulin $\mathrm{E}$ responses underlying asthma and rhinitis and chromosome 11q. Lancet 1, 1292-1295 (1989).

12. Shirakawa, I. et al. Atopy and asthma: genetic variants of IL-4 and IL-13 signalling. Immunol. Today 21, 61-64 (2000).

13. Pharoah, P. D. P. et al. Polygenic susceptibility to breast cancer and implications for prevention. Nature Genet. 31,33-36 (2002).

14. Splawski, I. et al. Variant of SCN5A sodium channel implicated in risk of cardiac arrhythmia. Science 297, 1333-1336 (2002).

15. Weber, W. W. Pharmacogenetics (Oxford Univ. Press, New York, 1997)

\title{
The Mona Lisa of modern science
}

\section{Martin Kemp}

Department of the History of Art, University of Oxford, Littlegate House, St Ebbes, Oxford OX1 1PT, and Wallace Kemp, Artakt, Studio D, 413-419, Harrow Road, London W93QJ, UK (e-mail: martin.kemp@trinity.ox.ac.uk)

No molecule in the history of science has reached the iconic status of the double helix of DNA. Its image has been imprinted on all aspects of society, from science, art, music, cinema, architecture and advertising. This review of the Mona Lisa of science examines the evolution of its form at the hands of both science and art.

"A monkey is a machine that preserves genes up trees, a fish is a machine that preserves genes in water; there is even a small worm that preserves genes in German beer mats. DNA works in mysterious ways." Richard Dawkins in The Selfish Gene (Oxford University Press, 1976).

$\mathrm{H}$ istory has thrown up a few superimages, which have so insinuated themselves into our visual consciousness that they have utterly transcended their original context. This is epitomized by the Mona Lisa, painted by Leonardo da Vinci around 1503. The double helix of DNA is unchallenged as the image epitomizing the biological sciences. Both images speak to audiences far beyond their respective specialist worlds, and both carry a vast baggage of associations.

In the worlds of popular image diffusion, particularly on the Internet, the double helix is beginning to rival the Mona Lisa as a playground for eccentrics and obsessives (Fig. 1). There is an apparent difference, of course. Leonardo's panel painting is the product of human artifice, whereas DNA is a naturally occurring, large organic molecule. But Leonardo claimed that his art represented a systematic remaking of nature on the basis of a rational understanding of causes and effects. His painting is the result of a complex, nonlinear interaction between concept, subject, plan of action, acquired knowledge, skill, medium and the evolving image itself. In The Art of Genes ${ }^{1}$, Enrico Coen argues that "biological development and human creativity are highly interactive processes in which events unfold rather than being necessarily pre-planned or anticipated. In other words, in both cases there is no easy separation between plan (or programme) and execution."

Looking at the investigation and representations of the double helix, we can say that

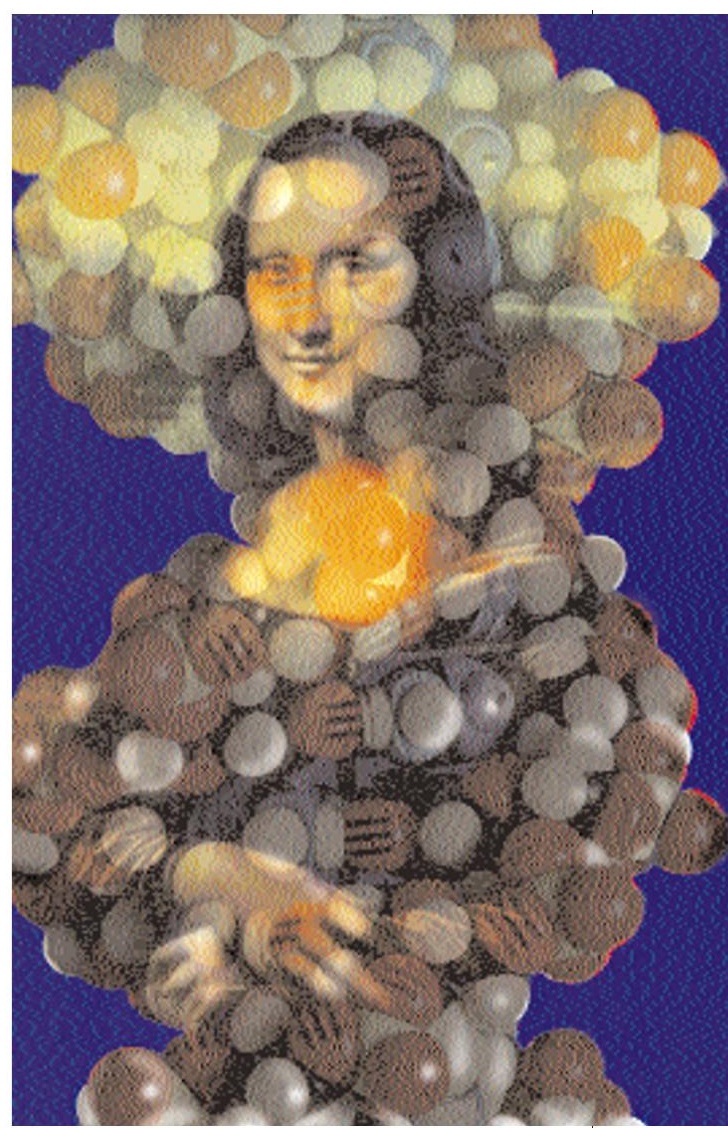

they are cultural activities no less than any painting. Behind the discovery lies the vast infrastructure of a scientific culture that led to the development of the knowledge, theories, institutions, techniques and equipment that made the quest both possible and desirable. The very natures of scientific models and representations, using whatever technique, are integral to the vehicles of science communication. Their visual look is compounded from a complex set of factors, ranging from technical to aesthetic. But, in case anyone should be getting the wrong impression, I acknowledge that the cultural vehicles are designed to deliver nonarbitrary information that is open to rational scrutiny as a way of working towards real knowledge of the physical constitution of the world.

Looked at from a popular perspective (and even from the standpoint of reputation within science), James Watson and Francis Crick are identified with DNA no less than Leonardo is identified with the Mona Lisa. The researchers were in a very real sense the 'authors' or 'artists' of the acts of visualization that generated their models of the molecule. But their brilliant achievement was not necessarily of a higher order than that of the other pioneers of molecular modelling, such as the Braggs, John Kendrew, Max Perutz, Maurice Wilkins and Linus Pauling. Rather, they were uniquely fortunate that their molecule was both visually compelling, as a supreme example of nature's 'sculpture', and 

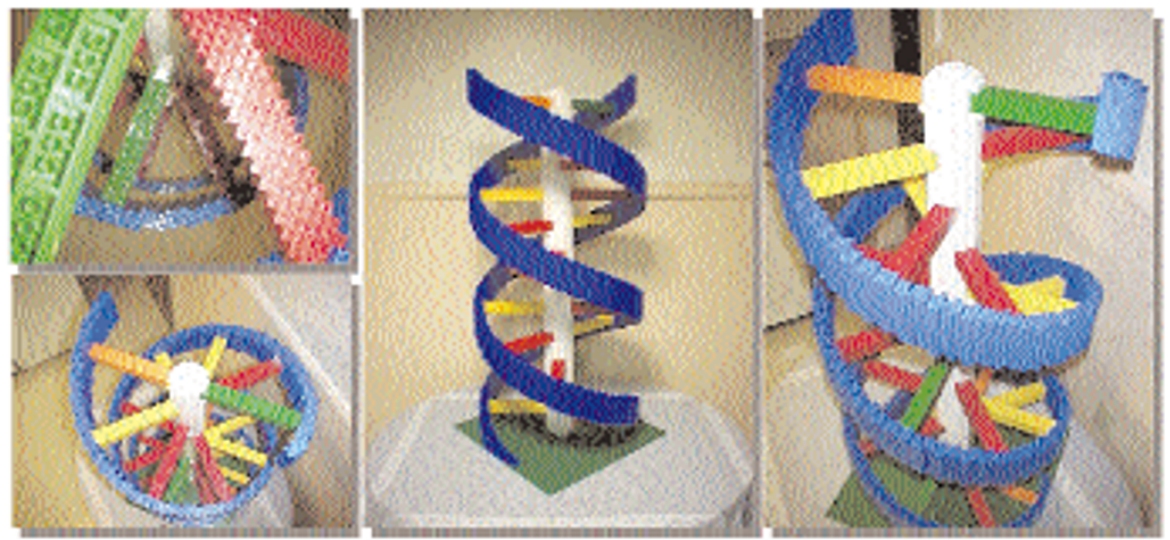

Figure 1 LEGO model of the DNA double helix (in reverse!) by Eric Harshbarger (2001), who also used his mastery of the coloured units of LEGO to compose a 'pixelated' LEGO version of the Mona Lisa. (Images courtesy of E. Harshbarger.) lay at the heart of the twentieth-century version of the quest to unravel the ultimate secret of life.

The 50-year journey of the DNA molecule from the reticent line diagram in Watson and Crick's seminal article ${ }^{2}$ (Fig. 2) to its position in today's world of global imagery is extraordinary. It is therefore timely to look at some of the representational issues involved in science communication, various guises in which the molecule has replicated itself within varied visual habitats.

\section{A model of communication}

Looking back on the laconic article in Nature that announced the structure of DNA, which we tend to assume in retrospect provided the definitive solution, it is remarkable how little was actually given away. This is true of the article's sole diagram, drawn by Odile Crick, Francis's wife, which represented the sugar chains as directional ribbons, while the bases were rudimentary rods represented flat on (Fig. 2). Along the vertical axis runs the central pole, depicted as a thick line that is broken where the bases lie in front. This axis is a visually useful point of reference, but its early ubiquity seems to depend on the structural necessities of physical models. The developed model, composed from standard brass components with tailor-made metal bases, provided a more detailed and explicit entity for debate and large-scale publicity, although the famous photographs by Anthony Barrington Brown (Fig. 3), taken for an article in Time magazine, were actually staged a few months later.

The model of the double helix - like those of other molecules, such as the model of haemoglobin by Perutz — played an important role in scientific understanding, being both based upon and in turn affecting the acts of scientific conceptualization. Overtaken by more refined models made at King's College London, including the widely illustrated space-filling model with Van der Waals surfaces by Wilkins (Fig. 4), the ramshackle masterpiece of Watson and Crick and then at a few selected instances of the passed the way of so many obsolete bits of scientific paraphernalia. When, 23 years after its making, some of the specially cut plates (Fig. 5) resurfaced in Bristol, they were incorporated into a pious reconstruction by Farooq Hussain of King's College. Like an ancient Greek vase reassembled from chards,

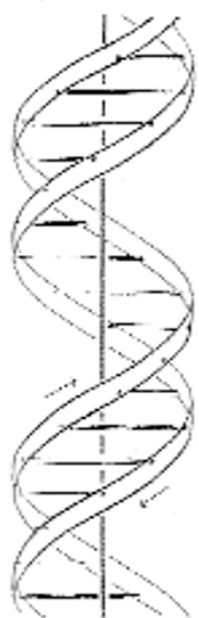

Figure 2 Structure of

DNA, drawn by

Francis Crick's wife

Odile Crick, which

was published as the

sole figure in Watson

and Crick's seminal

paper in Nature, 25

April 1953 (ref. 2).

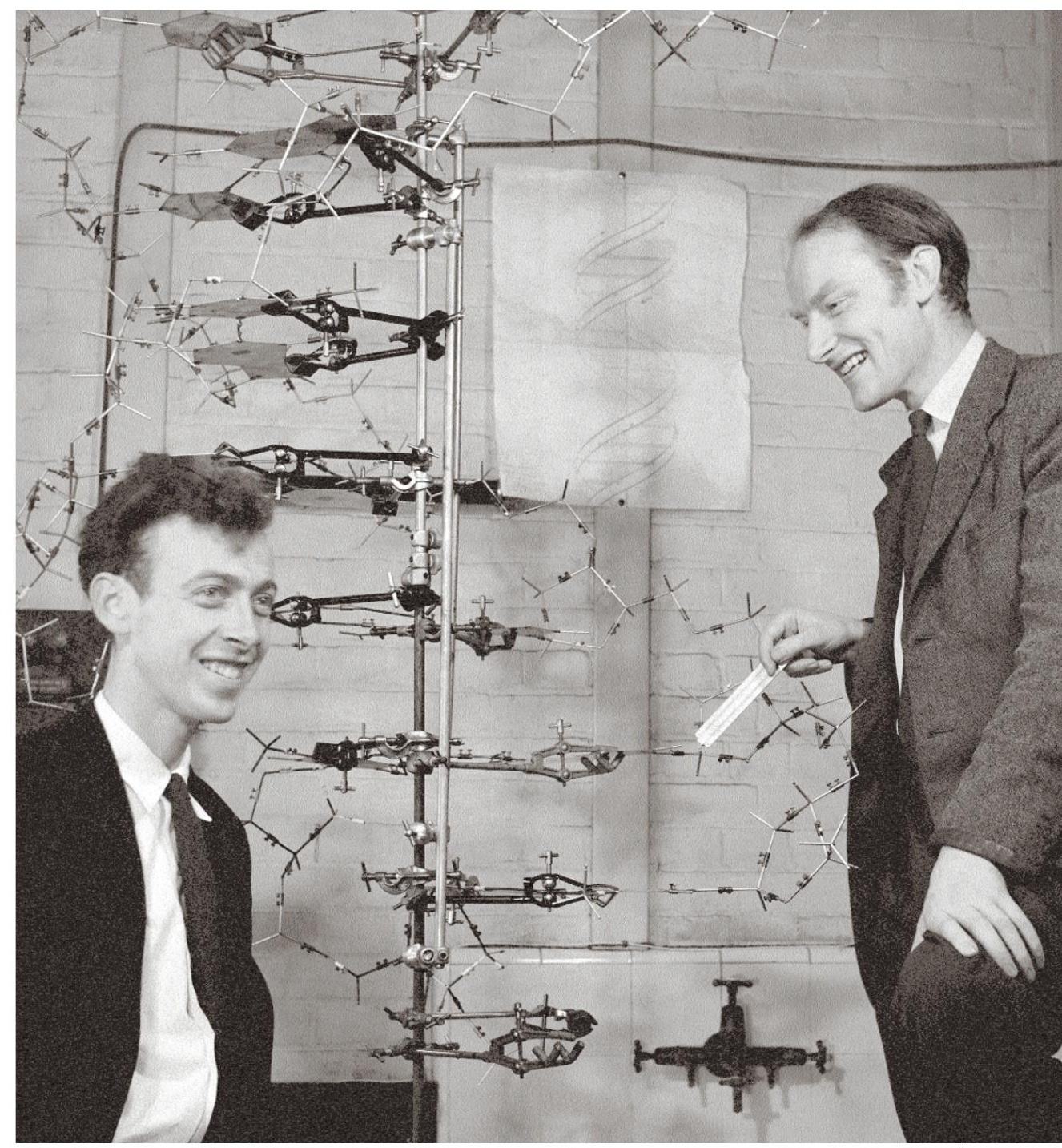

Figure 3 Anthony Barrington Brown's photograph of Watson and Crick with their model of DNA at the Cavendish Laboratory in Cambridge, 21 May 1953.

the semi-original model is now a treasured cultural icon, displayed in the Science Museum in London.

Communicating the complex structure and, in due course, the awesomely intricate behaviour of the modular molecule, has provided an unparalleled challenge for 


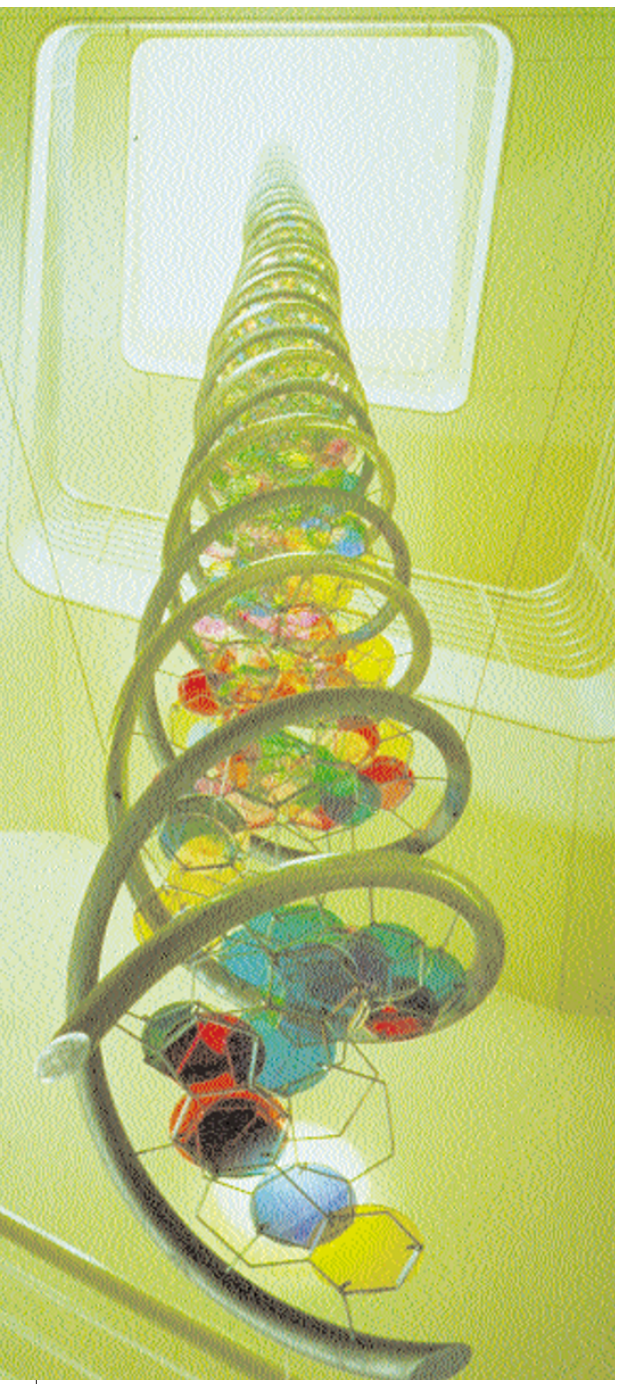

$\sum^{2}$

U modernism, Charles Jencks, it stands at the 5 heart of a programme of commissioning and $§$ collecting artwork that expresses the vision of Watson - who became director of Cold Spring Harbor Laboratory in 1968 and president in 1994 - of an environment in which the visual stimulation of the surroundings is integral to the conduct of high-level mental activity.

In pursuit of structural aesthetics, the British sculptor, Mark Curtis, proposed a reformed molecular structure for DNA. As an artist concerned with geometrical logic and symmetries, Curtis was worried about the 'ugly' engineering of the Watson-Crick version. Rather than using the sugar phosphate backbones to control the helices, he proposed that stacked base pairs, coupled in an opposite orientation from the accepted bonding, comprises a helix of pentagonal plates around a central void of decagonal cross-section. The geometrical and structural probity of Curtis's models, which eschew a central pole, made it on to a British millennium stamp (Fig. 9), if not into the world of scientific orthodoxy. In a real sense, the molecular biologists' rejection of Curtis's effort to re-design DNA on the basis of a priori principles represents an

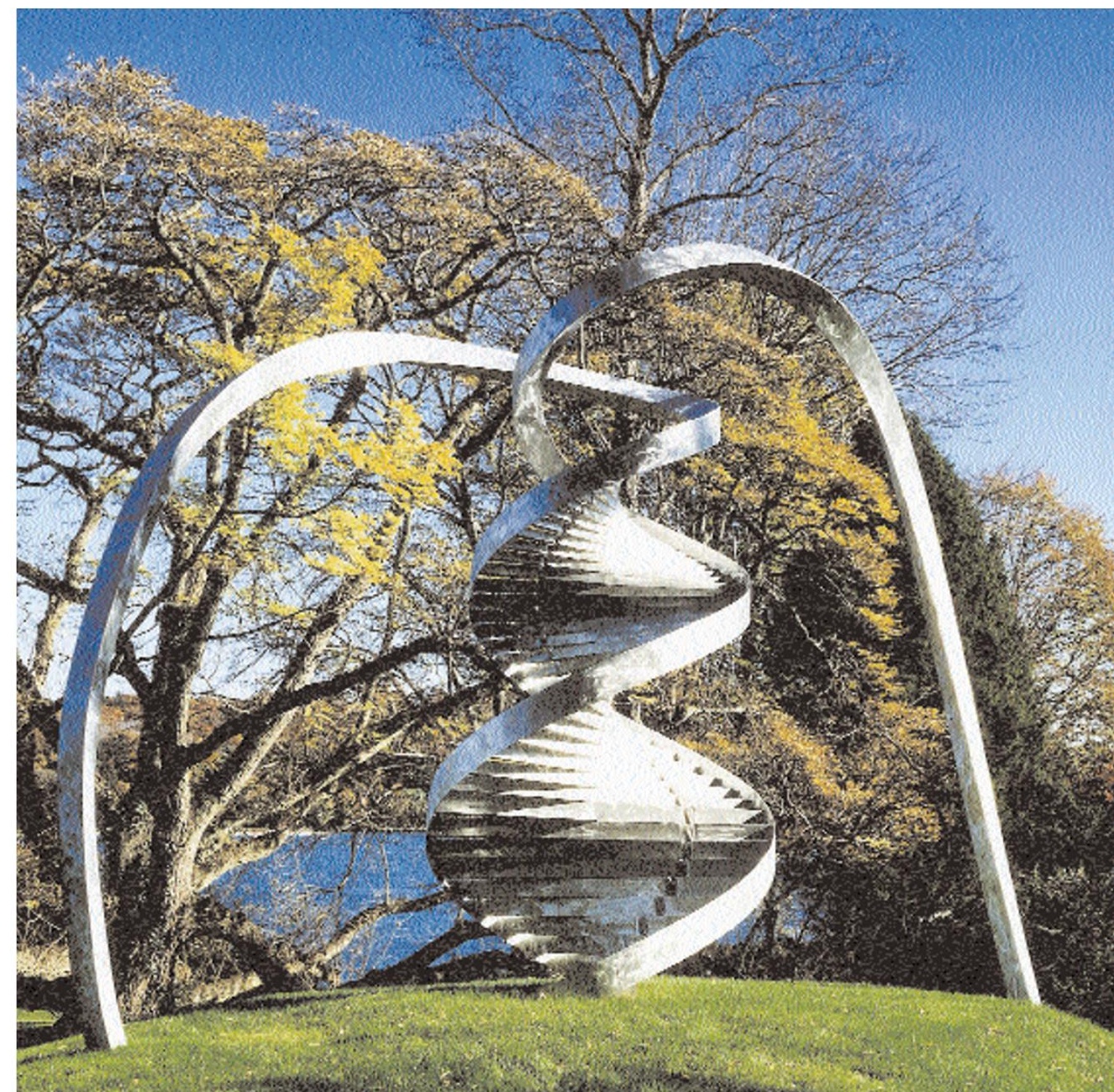

Figure 7 (left) Portrait of a DNA Sequence by Roger Berry (1998) at the Life Sciences Addition building, University of California, Davis. Figure 8 Spirals Time — Time Spirals by Charles Jencks (2000) at Cold Spring Harbor Laboratory.

extreme example of the tension within science itself between the polar instincts of the modellers and the empiricists.

Alongside such sculptural exploitations of the inherent beauty of the double helix has run a strand of artistic iconography that has been more overtly concerned with meaning. The tone for the more fantastical exploitations was set by the flamboyant surrealist, Salvador Dali, as ever concerned with the metaphysical potential implicit in scientific imagery. During the late 1950s and 1960s, the DNA molecule features as a symbolic vision, lurking in a surreal hinterland between galactic mystery and spiritual significance (as a kind of Jacob's Ladder). His Butterfly Landscape, The Great Masturbator in Surrealist Landscape with DNA (1957-8; Fig. 10) locates a prettified evocation of a space-filling model in one of Dali's typically barren landscapes inhabited by sub-Freudian enigmas, designed to conjure up a dreamworld of obscure sexual fantasy ${ }^{4}$. Subsequent artists, particularly those who have engaged with the social implication of molecular biology and genetic engineering, have located images of DNA in contexts of meaning that are less obscure and more polemic.

This savagely selective glance at DNA art — omitting such contemporary luminaries of genetic art as Suzanne Anker ${ }^{5}$ (Fig. 11; www.geneculture.org), David

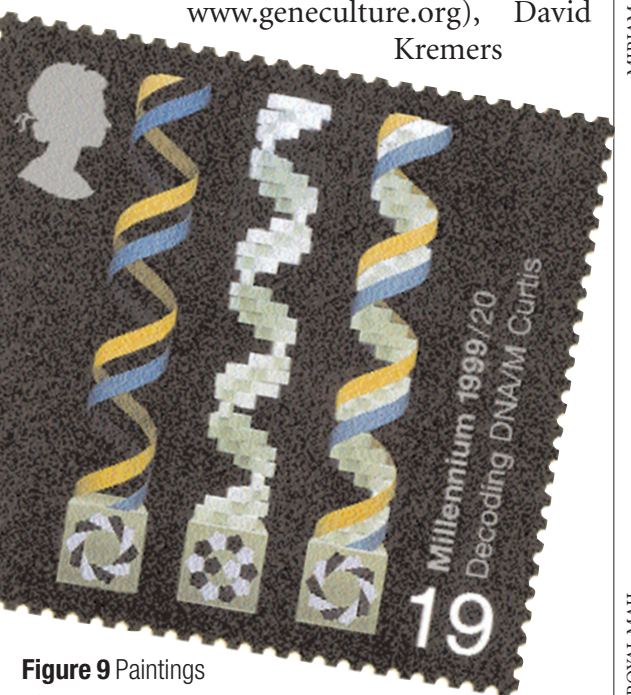

of DNA models on a 'Millennium

Collection' stamp, designed by Mark Curtis

(1999-2000), from the UK Royal Mail's Scientists' Tale collection. 


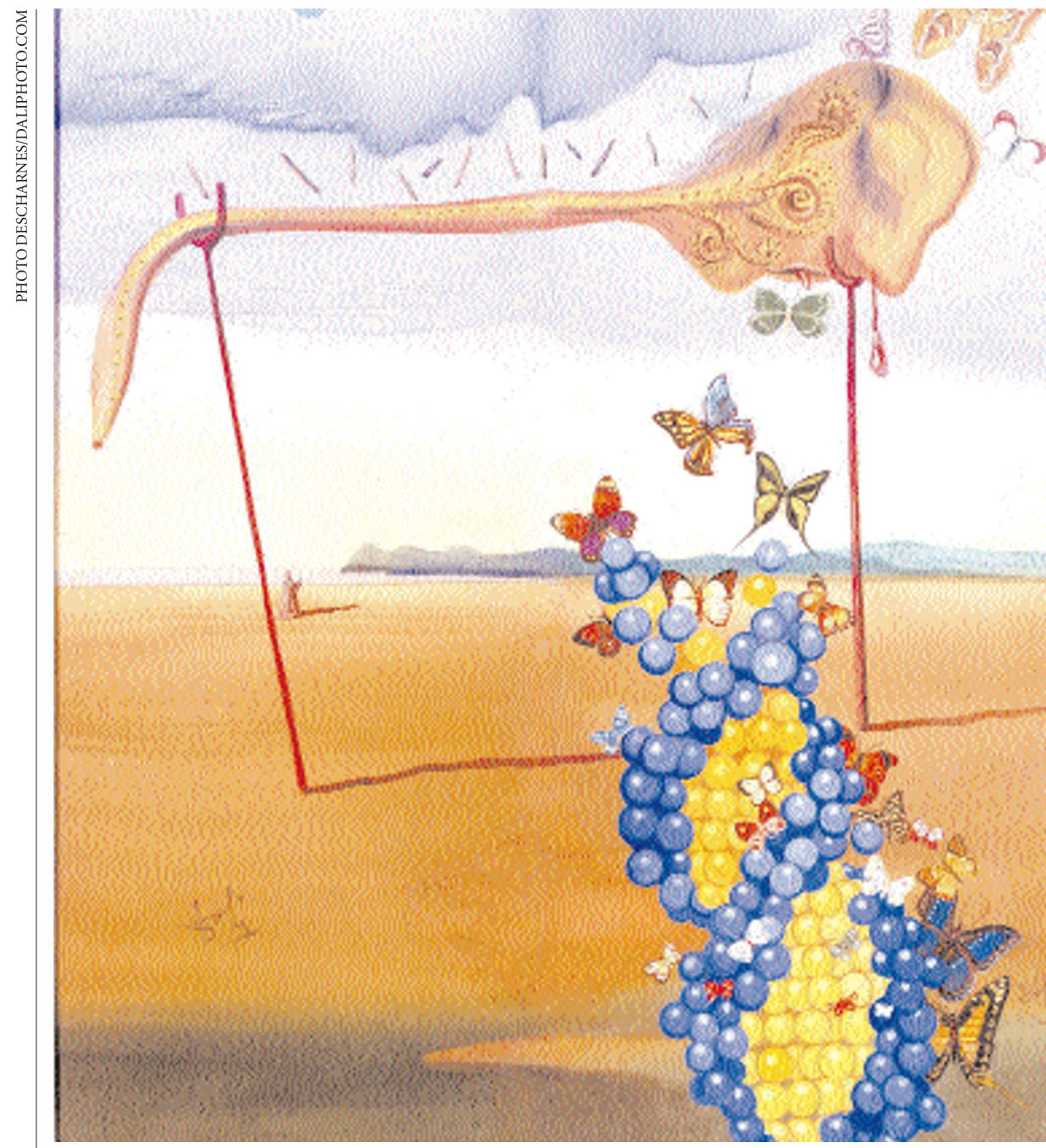

Figure 10 Butterfly Landscape, The Great Masturbator in Surrealist Landscape with DNA by Salvador Dali, 1957-8. Private collection.

(http://davidkremers.caltech.edu/), Ellen Levy (http://www.geneart.org/genomelevy.htm), Sonya Rapoport (http:// users.lmi.net/sonyarap/transgenicbagel/) and Gary Schneider (http://www.icp.org/ exhibitions/schneider/) — can barely claim to be representative even of the main range of possibilities. In particular, exploitation of the replicating potential of DNA to generate self-organizing images - exemplified by Marc Quinn's genetic portrait of Sir John Sulston from Sulston's own DNA, fragmented and replicated in bacterial colonies on plates of agar jelly ${ }^{6}$ - shows that some artists' engagement with DNA is maturing beyond iconographical opportunism.

Box 1

\section{3 exhibitions celebrating art in the age of the double helix}

2003 is to throw up a series of exhibitions, including:

- Representations of the Double Helix, at the Whipple Museum of the History of Science,

Department of History and Philosophy of Science, University of Cambridge, UK. The

exhibition is curated by Soraya de Chadarevian and Harmke Kamminga, with the assistance

of Corrina Bower, and will run from January to December 2003.

- Genetic Expressions: Art After DNA, at the Heckscher Museum of Art, Huntington,

New York. Curated by Elizabeth Meryman and Lynn Gamwell, the exhibition will run from 28

June to 7 September 2003.

- From Code to Commodity: Genetics and Visual Art, at the New York Academy of Sciences. The exhibition runs from 13 February to 11 April 2003 and is curated by Dorothy Nelkin and Suzanne Anker. Cold Spring Harbor Laboratory Press are publishing a book by Nelkin and Anker entitled The Molecular Gaze: Art in the Genetic Age.

- PhotoGENEsis: Opus 2 - Artists' Response To the Genetic Information Age, at the Santa Barbara Museum of Art, 9 November 2002-9 February 2003.

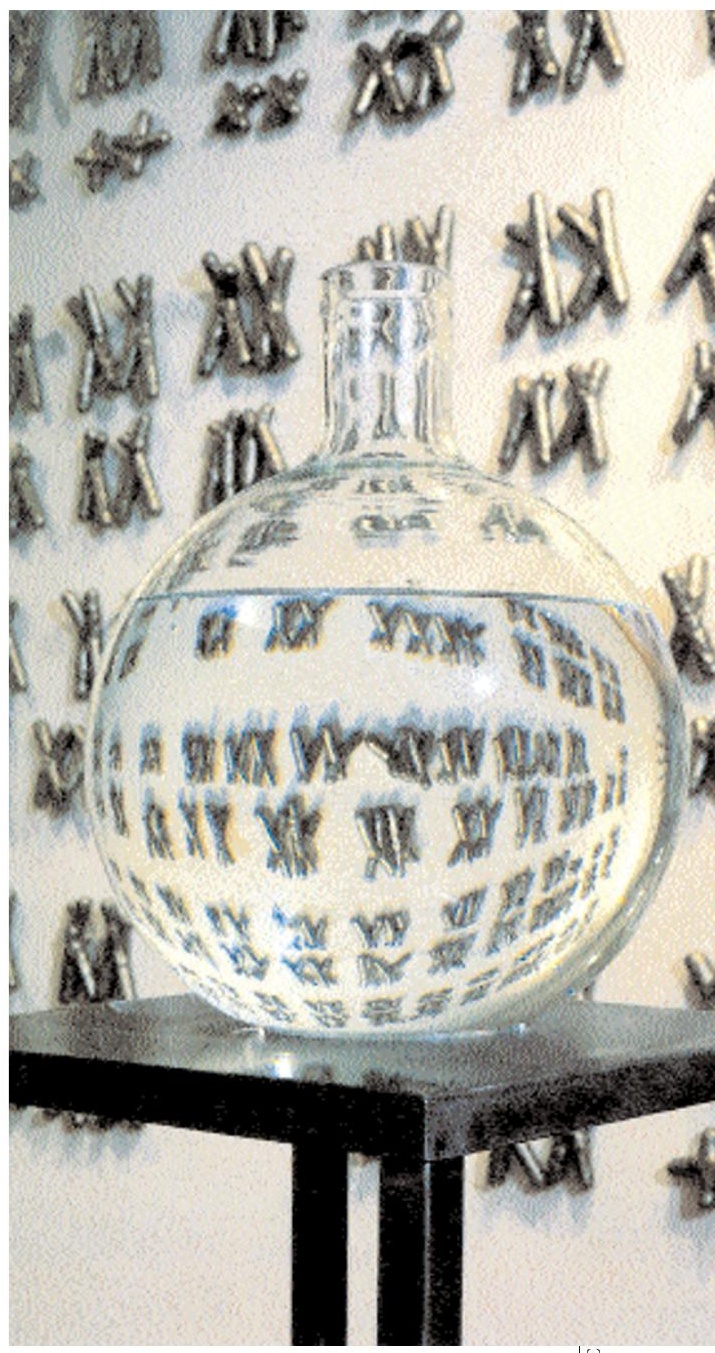

Figure 11 Zoosemiotics: Primates, Frog, Gazelle, Fish (detail) by Suzanne Anker (1993).

But as with the Mona Lisa, opportunism will always be the name of a prominent public game. Typical of this tendency is the introduction by the perfume company Bijan in 1993 of a fragrance named DNA. Ironically, we learn from the maker's blurb that "DNA is recommended for casual use". Such is the destiny of one of the greatest popularicons.

doi:10.1038/nature 01403

1. Coen, E. The Art of Genes. How Organisms Grow Themselves

(Oxford Univ. Press, Oxford, 1999).

2. Watson, J. D. \& Crick, F. H. C. A structure for deoxyribose nucleic acid. Nature 171, 737-738 (1953).

3. Watson, J. D. Molecular Biology of the Gene (W. A. Benjamin, Inc., New York, 1965).

4. Descharnes, H. \& Neret, G. Salvador Dali 1904-1989 (Taschen, New York, 1998).

5. Nelkin, D. \& Anker, S. The influence of genetics on

contemporary art. Nature Rev. Genet. 3, 967-971 (2002).

6. Kemp, M. Reliquary and replication. A Genomic Portrait: Sir John Sulston by Marc Quinn. Nature 413, 778 (2001).

\section{Acknowledgements}

R. Hodgson provided research assistance. Important advice has been gratefully received from S. de Chadarevian and H. Kamminga of the Department of the History and Philosophy of Science at Cambridge University, E. Levy, E. Coen, and K. Roberts of the John Innes Centre at Norwich. 